\title{
Structure, Conduct and Performance of Groundnut Markets: The Case of Fogera Woreda, South Gondar Zone of Amhara Regional State
}

\author{
Wubalem Gobie ${ }^{1}$, Teshale Wolde Amanuel ${ }^{2}$, Tewodros Tefera ${ }^{2}$ \\ ${ }^{1}$ Department of Agribusiness \& Value Chain Management, Debre Markos University, Debre Markos, Ethiopia \\ ${ }^{2}$ School of Environment, Gender and Development Studies, Hawassa University, Hawassa, Ethiopia
}

Email address:

wge2006@gmail.com(W. Gobie), twamanuelh@gmail.com (T. Woldamanuel), dagted@gmail.com (T. Tefera)

\section{To cite this article:}

Wubalem Gobie, Teshale Wolde Amanuel, Tewodros Tefera. Structure, Conduct and Performance of Groundnut Markets: The Case of Fogera Woreda, South Gondar Zone of Amhara Regional State. International Journal of Agricultural Economics.

Vol. 4, No. 2, 2019, pp. 55-69. doi: 10.11648/j.ijae.20190402.13

Received: February 17, 2019; Accepted: March 22, 2019; Published: April 26, 2019

\begin{abstract}
This paper looks at and assesses the structure, conduct and performance of groundnut markets in Fogera Woreda, South Gondar Zone of Amhara Regional State. Households and traders concerned in groundnut were interviewed for obtaining primary data. The study was conducted by incorporating from two kebeles of 175 groundnut producing households and seven markets of 34 traders. A multi stage sampling procedures were employed to select sample producers while for groundnut traders snowball sampling techniques was used. The result shows that nine major groundnut marketing channels were identified and using the respondents a total of 7432.8 quintals of groundnuts were transacted in 2015/16 production season and among its rural assemblers and urban wholesalers purchased about $66.7 \%$ and $29.33 \%$ of the total produce respectively. The analysis of the market structure indicates that the concentration ratio of $76.61 \%$ at Bahirdar market, which shows an oligopolistic market structure and which resulted in a groundnut market conduct characterized by a market strategy in which the traders have an upper hand in fixing the price of the groundnut as well as effecting payment by the time in favor of the traders. Concerning the market performance, the findings show that the benefit from groundnut marketing is skewed to few actors in the market chain. Notably, street vendors had the highest gross marketing margin with estimated share of $51 \%$ found in the channel III and followed processors and urban retailers with estimated share of $43.7 \%$ and $38.89 \%$ in channel I and II of the consumer's price respectively. The highest total gross marketing margin found in channel IX which accounts for $64.81 \%$ of the consumer's price and followed by channel VII and VIII which accounts each with estimated share of $64.05 \%$ of the consumer's price. The lowest producers' share is appropriated in channel IX which accounts $35.19 \%$ of the consumer's price. The findings from this study, so strongly recommended that establishing well organized cooperatives for reducing the inefficiency due to high marketing margin as well as the oligopolistic market structure.
\end{abstract}

Keywords: Groundnut Market, Structure, Conduct, Performance, Fogera Woreda

\section{Introduction}

Agriculture remains the primary activity in Ethiopia about $82 \%$ of the country's population is engaged in various agricultural activities and generates its income for household consumption to sustain its livelihood. Moreover, the country generates the lion share of its foreign currency earnings and currently the sector contributed $45 \%$ to the country's GDP and so the sector played a great role for sustainable economic development of the country [13]. Ethiopia designed agricultural development strategy known as Agricultural Development Led Industrialization (ADLI) considered agriculture as the engine of growth on account of its potentiality to linkages, surplus generation, potential market creation, provision of raw materials and foreign exchange earnings and assured mainly by improving the performance of agricultural marketing system [4]. Furthermore, scientific investigation carried out by identifying the marketing constraints and opportunities for the sector in general and the commodity in particular has been a paramount importance to tackle the existence constraints and also to 
capitalize the opportunities as well [18]. National Bank of Ethiopia [21] report indicated that Oilseeds are one of the major export commodities to generate revenue in Ethiopia. In 2012/13 production season, oilseeds were the third largest export earner after coffee and gold accounted for $14 \%$ of total exports. However, export of oilseeds is significantly dominated by one commodity - Sesame which constitutes about $79 \%, 11 \%$ of Niger seed, $5 \%$ of groundnut and 3\% castor bean. Furthermore, the Central Statistical Agency [9] of Ethiopia stated that oil crops used to cover about 0.86 million hectares, involving close to four million small holder producers in Oromia, Amhara, Tigray, and Benishangul- Gumuz Regional States and the report shown that groundnut (Arachis hypogaea L) production was 1.24 million quintals which leads to improve the living standard of smallholder producers by generating income in the form of cash as well as for households' consumption. Groundnut is one of the five widely cultivated oilseed crops in Ethiopia [28]. It generates considerable cash income for several small scale producers and foreign exchange earnings through export for the country [12]. In addition, it has nitrogen fixing ability and making them ideal for crop rotation with cereal crops like maize [16]. Ethiopian agricultural output markets are characterized by inadequate transport network, limited number of traders, high handling costs, inadequate market information system, weak bargaining power of producers and underdeveloped industrial sectors. Due to this reason, producers in Ethiopia were more focused on the volume of production part without having adequate market information about their produced [15]. In similar manner, producers in Ethiopia in general and in Amhara region in particular are affected by low producer's price, in one hand side, and high consumer's price, on the other hand; one of the reasons for this was lack of proper transport facilities and other infrastructure services i.e. market development, access to technology [29]. In addition, that an informed policy decision in regards of improving the performance of the agriculture marketing system needs updated information on the existing structure, conduct, and performance of the market [2]. Moreover, a lot of efforts have been invested by the government to produce surplus oil crops for export purpose. However, the significance of groundnut in the livelihoods of producers and traders as an income generating crop, has not been given due attention most especially in the area of marketing as sesame [21]. Research done on groundnut includes performance of groundnut varieties [10], response of groundnut to different rate of phosphorus fertilizers [6], design and development of groundnut Sheller [13]. Studies conducted on market chain analysis tends to focus on vegetables (tomato and onion), and rice in the woreda [1] and [5]. However, the marketing aspect of groundnut, which is one of the major cash crops in the area, was not investigated. Hence, this study was initiated and investigated the different marketing actor's, roles, and their linkage, and the structure, conduct and performance of groundnut and study was designed to address the existing information gap on the subject and contributed for the proper understanding of the challenges and improves the market development strategies for benefiting producers, traders, and other market participants.

\section{Objectives of the Study}

The general objective of this study was to discover the structure conduct and performance of groundnut in Fogera Woreda with the following specific objectives:

1) To identify the major actors in groundnut marketing chain and examine their roles and linkages

2) To investigate the market structure, conduct and performance of groundnut

\section{Methodology}

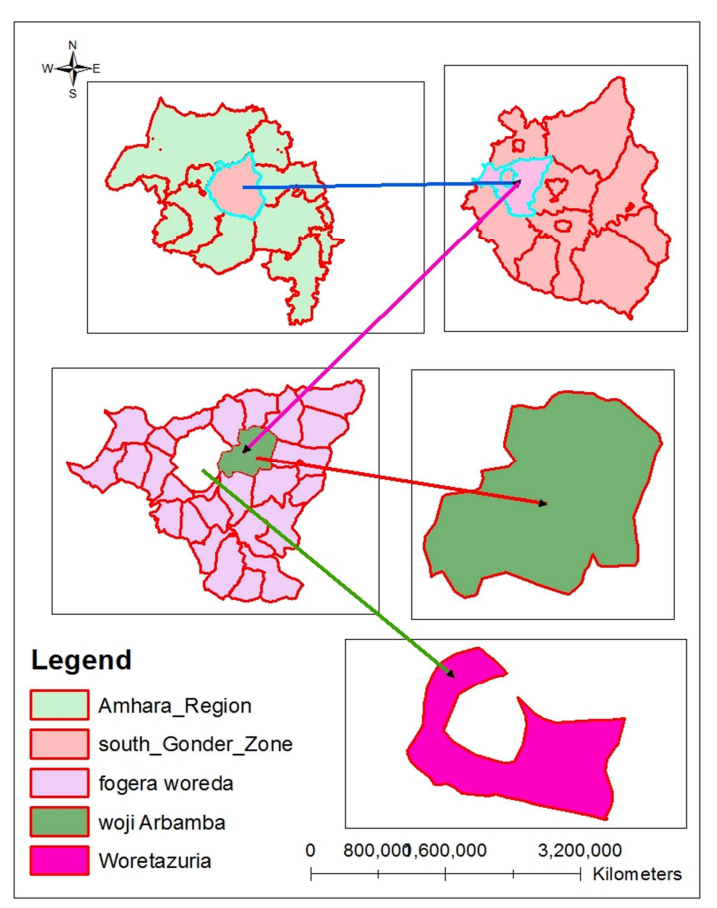

Source: Bureau of Agriculture and Rural Development, 2016

Figure 1. Depicted that map of the study areas.

Fogera Woreda is one of the 106 Woredas in Amhara National Regional State (ANRS) which is found in South Gondar Zone. It is situated in $11^{0} 58^{\prime} \mathrm{N}$ latitude and $37^{\circ} 58^{\prime} \mathrm{E}$ longitude. Woreta is the town of the Woreda and found in 625 $\mathrm{Km}$ from Addis Ababa and 55Km from the Regional capital, Bahirdar. It is also located $42 \mathrm{Km}$ from Debre-Tabour which is the capital city of South Gondar Zone (IPMS, 2016). Its annual rainfall ranges from $1103 \mathrm{~mm}$ to $2400 \mathrm{~mm}$ with a mean annual rainfall of $1751 \mathrm{~mm}$ and it has $100 \%$ Woina dega weather condition. The temperature ranges from 11.48 degree celcious to 27.3 degree celcious and its altitude ranges from 1774 to 2410 masl which allowing a favorable weather condition for wider crop production i.e. teff, rice, finger millet, maize, pepper, groundnut and livestock rearing [ 16], average land holding was about 1.4 ha with minimum and maximum of 0.5 and 3.0 ha, respectively.

Both primary and secondary sources of data were used to achieve the desired objectives. The primary data were collected from sample of respondents. The primary data were collected using two types of surveys, one used for groundnut 
production and socio-economic characteristics of households and the other interview schedule for traders i.e. urban wholesalers, urban retailers, processors, Balitinas, vendors, urban collectors and rural assemblers, buying and selling strategies, sources of groundnut market information, price setting strategy, payment strategy and annual volume of sales collected data were used to investigate the S-C. P of market as well as socio-economic characteristics of traders. In addition, the secondary data were collected from different sources i.e. government organizations (central statistical agency, office of agriculture \& rural development, office of finance and economic development and websites.

A multistage sampling technique was employed to select groundnut producing households. In the first stage, Fogera woreda was selected purposively since potentially groundnut is produced in the study areas. In the second stage, two groundnut producing out of seven kebeles in the woreda were purposively selected based on production potential with recommendation of woreda agricultural office leaders and development Agents. Then by using the probability proportional to size of households 116 households $(66 \%)$ from Woji Arbamba kebele and 59 (34\%) from Woreta Zuria kebele were determined. A piece of paper 180 prepared and properly folded and reserve five used for the sake of unvolunteered respondents. Finally, from the sample frame 175 households were selected by random sampling technique and interviewed. Sample size was determined by using a simplified formula to calculate sample sizes [33] as follows:

$$
\mathrm{n}=\frac{\mathrm{N}}{1+\mathrm{N}(\mathrm{e})^{2}}
$$

Where $\mathrm{n}$ is sample size, $\mathrm{N}$ is the population size and e is the level of precision. However, due to the absence of recorded secondary data to get the name of traders and prepared sample frame from office of trade and industry, the researcher obliged to use snowball sampling procedure to identify respondents from the selected markets and from 34 traders' were interviewed and primary data collected.

Focus Group selection: for collecting primary data focus group discussion is one of the informal survey. Respondents involved with better groundnut farming experience, adult producers as well as female producers were selected to discuss issues related to the objective of the study by forming a small group with a group size of eight. The reason of selecting the participants were to assess thoroughly the groundnut producing ability i.e. searching and getting market information as well as production information. Two focus group discussions were conducted for each kebele before the questionnaire administered followed the data collected. However, at the end of the survey additional focus group discussion was not conducted since in the two cases the data collected were similar and enumerators were familiar in the study areas. The discussion was facilitated by preparing a check list of the researcher together with trained enumerators and group participants were encouraged to deal freely about the specific objectives of the study. In addition, Key Informants discussion were made with those experts who had better experience, active involvement and knowledgeable in the area of groundnut production and marketing information. Among development agents, office of agricultural experts as well as researchers was interviewed and data incorporated.

Household Survey: structured and semi-structured questionnaires were prepared for the household as well as trader survey based on the data draw out through key informant interviews and focus group discussions. The survey data were collected through structured and semistructured questionnaires administered by face to face interview of household heads and traders. The survey was conducted January to February 2017. Enumerators from the study areas had grade 12 students and BSc holders. They were familiar about the study areas as well as they can easily communicate with the respondents and they know the respondents living style, culture and traditions. Hence, the roles of the enumerators were to induce the producers to respond voluntarily without hesitation and gave the actual data during the interview. However, the role of researcher was facilitation as well as supervision.

\subsection{Methods of Data Analysis}

For data analysis of this study, descriptive statistics was employed. The descriptive statistics like mean, min, max, standard deviation, percentages and frequencies were used to scrutinize and understand the socio-economic characteristics of the respondents as well as the structure, conduct and performance of groundnut market. The data were analyzed by using software application of Statistical Package for Social Science (SPSS) version 20 and Standard Statistical Package for Analysis of Data (STATA) version 12. It was also used this model to evaluate food grain market in Alaba Siraro district [32], and again the model used to evaluate pepper market in Alaba and Siltie in SNNPRS of Ethiopia [26] and to evaluate red pepper market Bure Woreda, West Gojjam Zone, ANRS, Ethiopia [3]. This study also used S-C$\mathrm{P}$ model to evaluate groundnut market in Fogera woreda. The analytical framework / procedure of Structure, conduct and Performance of groundnut market was depicted as follows:

\subsection{The Structure of the Market of Groundnut}

The term market structure refers to a set of market characteristics that determine the economic environment in which a firm operates [29]. Mostly emphasized in market structure are the number of independent buyers and sellers, the degree of buyers and sellers concentration and the condition of entry into the market. Analyzed the structure of the market in Fogera woreda in order to comprehend the organization of the market and assess the degree of competition in groundnut markets using Concentration ratio. Concentration ratio is a mathematical index which was widely used by industrial organizations for measuring the size of firms in market [28]. As rule of thumb, a four largest enterprises concentration ratio of 50 percent or more is an indication of a strong oligopolistic industry, 33-50 percent, a weak oligopoly, and less than or equal to $33 \%$ is an indication of non-concentrated industry [21]. The greater the 
degree of concentration ratio is the greater the possibility of non-competitive behavior existing in the market and thus leads to market inefficiency. So, the method of analyzing market structure specified as:

$$
\mathrm{S}_{\mathrm{i}}=\frac{\mathrm{v}_{\mathrm{i}}}{\sum \mathrm{v}_{\mathrm{i}}}
$$

Where $S_{i}=$ market share of the $i^{\text {th }}$ buyer

$\mathrm{V}_{\mathrm{i}=\text { amount }}$ of product handled by the $\mathrm{i}^{\text {th }}$ buyer

$\Sigma \mathrm{V}_{\mathrm{i}}=$ Total amount of product purchased

$$
\mathrm{C}=\sum_{\mathrm{i}=1}^{\mathrm{m}} \mathrm{S}_{\mathrm{i}}, \mathrm{i}=1,2, \ldots \mathrm{m} .
$$

Where $\mathrm{C}=$ concentration ratio, $\mathrm{S}_{\mathrm{i}}$ percentage share of the $i^{\text {th }}$ firm and $m=$ numbers of largest firms for which the ratio was calculated.

\subsection{The Conduct of the Market of Groundnut}

Market conduct refers to the patterns of behaviors that firms follow in adapting or adjusting to the markets in which they sell or buy. The dimensions of conduct include methods employed by firms in determining the price of an output and sales promotion policy, the presence or absence of coercive tactics directed against either established rivals or potential entrants [6].

\subsection{The Market Performance of Groundnut}

Market performance refers to the economic results that flow from the industry and how well it performs in terms of efficiency and progressiveness or innovation, given its technical environment [6]. Performance of the market is a reflection of the impact of structure and conduct on product price, costs and the volume and quality of output [9]. If the market structure in an industry resembles monopoly rather than pure competition, then one expects poor market performance. Market performance is the end result of the market adjustments engaged in by buyers and sellers. To evaluate a market performance, the marketing margin was analyzed.

$$
\mathrm{TGMM}=\frac{\text { End buyer Price -First seller price }}{\text { End buyer Price }} * 100
$$

Where, TGMM $=$ Total gross marketing margin The producer's margin is calculated as:

$$
\mathrm{GMM}_{\mathrm{P}}=\frac{\text { End buyer Price -marketing Gross margin }}{\text { End buyer Price }} * 100
$$

The net marketing margin (NMM) is the percentage of the final price earned by the intermediaries as their net income after their marketing costs were deducted. The percentage of net income that can be classified as pure profit (i.e. return on capital) depends on the extension to such factors as the intermediaries' own (working capital) costs.

Or GMMp equal to one minus the complete gross marketing margin of the marketing channel

$$
\mathrm{NMM}=\frac{\text { Gross margin }- \text { marketing costs }}{\text { End buyer Price }} * 100
$$

Where, $\mathrm{NMM}=$ Net marketing margin

\section{Results and Discussions}

\subsection{Socio-Economic Characteristics of Sample Producers and Traders}

The socio-economic characteristics of producers described as in terms of sex, religion, marital status, education level, age of household and family size of producers are presented in Table 1. Sex of the sample producers were compared between the two research areas (Woji Arbamba \& Woreta Zuria) and $95 \%$ of the sample respondents were males and the rest were females. This is linked with the marital status of the respondents which indicates that the majority $(93.7 \%)$ of them were married. Concerning about religion, $68 \%$ were Muslims and the rest $32 \%$ were Orthodox religious

\begin{tabular}{|c|c|c|c|c|c|}
\hline Variables & & $\mathrm{N}=116$ Woji Arbamba & $\mathrm{N}=59$ Woreta Zuria & $\mathrm{N}=175$ Total & $\chi^{2}$ value \\
\hline \multirow{2}{*}{ Sex } & Male & 94.8 & 96.6 & 95 & \multirow{2}{*}{0.285} \\
\hline & Female & 5.2 & 3.4 & 5 & \\
\hline \multirow{2}{*}{ Religion } & Orthodox & 17.2 & 61 & 32 & \multirow{2}{*}{$34.441 * * *$} \\
\hline & Muslim & 82.8 & 39 & 68 & \\
\hline \multirow{3}{*}{ Marital status } & Single & 0.9 & - & 0.6 & \multirow{3}{*}{6.066} \\
\hline & Married & 93.1 & 94.9 & 93.7 & \\
\hline & Divorced & 6 & 1.7 & 4.6 & \\
\hline
\end{tabular}
followers. However, as table 1 chi-square result revealed that there is a statistically significant difference in religion in the two research areas at less than $1 \%$ level of significance.

Table 1. Socio-economic characteristics of sample producers (in percentage).

$\mathrm{N}=$ Sample size ${ }^{* * *}$ show statistically significant at less than $1 \%$ significant level

Source: Survey result, 2017

The result in table 2 shows that average age of the sample producers was 45 which range between 25 and 78 years respectively with standard deviation of 11.32 . As Table 2 suggested that farming income was the main sources of the sampled household respondents. On average the annual farming income of the sampled household in the year 2015/16 was Birr18, 830.86 per household and the minimum and maximum annual farming income of the sample producers were Birr2, 500 and Birr 55,000 respectively. 
Table 2. Household characteristics, farming \& resource ownership of sample producers in 2015/16.

\begin{tabular}{lllll}
\hline Characteristics & N & Minimum & maximum & Mean \\
\hline Age of household & 175 & 25 & 78 & 45 \\
No of family size (active labor force) & 175 & 1 & 7 & 11.32 \\
Annual farming income (Birr) & 175 & 2,500 & 55,000 & 1.221 \\
TLU & 175 & 0 & 14.69 & $18,830.86$ \\
\hline
\end{tabular}

$\mathrm{N}=$ Sample size

Source: Own computation, 2017

To evaluate the livestock holding of each household, the Tropical Livestock Unit (TLU) per household was calculated. As it is indicated in Table 2 the sampled respondents on average had more than 5 livestock per household head. The result in Table 2 shows that the maximum number of livestock ownership was 14 whereas the minimum numbers of them were zero livestock ownership with the standard deviation of 3.221.

Table 3. Producers access to price information (percentage of producers).

\begin{tabular}{|c|c|c|c|c|c|}
\hline \multicolumn{2}{|l|}{ Variables } & $\begin{array}{l}\mathrm{N}=116 \\
\text { Woji Arbamba }\end{array}$ & $\begin{array}{l}\mathbf{N}=59 \\
\text { Woreta Zuria }\end{array}$ & $\begin{array}{l}\mathrm{N}=175 \\
\text { Total }\end{array}$ & $\chi^{2}$-value \\
\hline \multicolumn{2}{|c|}{ Information on nearby market price (yes, $\%$ ) } & 39.7 & 55.9 & 45.1 & $4.184 * *$ \\
\hline \multicolumn{2}{|c|}{ Information on Bahirdar market price (yes, $\%$ ) } & 1.8 & 2.6 & 2.3 & 0.122 \\
\hline \multirow{4}{*}{$\begin{array}{l}\text { Sources of } \\
\text { information }\end{array}$} & Other groundnut traders $(\%)$ & 9.5 & 6.8 & 8.6 & \multirow{4}{*}{$29.483 * * *$} \\
\hline & Telephone $(\%)$ & 3.4 & 6.9 & 5.7 & \\
\hline & Personal observation $(\%)$ & 44.8 & 39 & 42.9 & \\
\hline & Other groundnut traders \& personal observation $(\%)$ & 11.2 & 1.7 & 7.4 & \\
\hline Was informat & a reliable (yes, $\%$ ) & 26.1 & 34.5 & 28.9 & \\
\hline Was informat & reliable (no, $\%$ ) & 73.9 & 65.5 & 71 & \\
\hline
\end{tabular}

$\mathrm{N}=$ Sample size $* * *$ and $* *$ values show statistically significant at less than $1 \%$ and $5 \%$ significant level respectively

Source: Survey result, 2017

According to Table 3 presented that about $2.3 \%$ of the total sampled households had obtained the demand, supply and price information at Bahirdar market before sold their produce. Even though, knowing the Bahirdar market price before sold the volume of produced, almost Woreta Zuria 3\% of the producers had obtained Bahirdar market price better than that of Woji Arbamba almost $2 \%$ producers due to its proximity of the woreda as well as the regional market.

The sampled respondents were asked about the sources of groundnut market information and Table 3 revealed that almost about $43 \%$ of the total sampled respondents had obtained groundnut market information from personal observation. Almost $45 \%$ of the Woji Arbamba producers had obtained market information from personal observation than about $39 \%$ of Woreta Zuria producers. On the other hand, about $48 \%$ of the sampled household heads of Woreta
Zuria producers had obtained market information from personal observation $\&$ neighboring producers more than that of only almost $28 \%$ of Woji Arbamba producers.

According to Table 3 the chi-square result revealed that there is statistically significant difference at less than $1 \%$ level of significance about the sources of market information in the study areas.

The result in Table 3 presented that about almost $29 \%$ of the sample respondents confirmed that the informal market information was reliable and the rest $71 \%$ of the respondents were confirmed that the informal market information was not reliable because the price fluctuation. Therefore, the survey result indicated that access to market information was obtained from informal sources and information has been scanted.

Table 4. Storage time, storage system and storage purpose of groundnut (in percentage).

\begin{tabular}{|c|c|c|c|c|c|}
\hline Variables & & $\begin{array}{l}\mathrm{N}=116 \text { Woji } \\
\text { Arbamba }\end{array}$ & $\begin{array}{l}\mathrm{N}=59 \text { Woreta } \\
\text { Zuria }\end{array}$ & $\mathrm{N}=175$ Total & $\chi^{2} / t-$ value \\
\hline Did you & Store $(y e s, \%)$ & 90.5 & 96.9 & 93.7 & $5.970 * * *$ \\
\hline Did you sold & Immediately (yes, \%) & 32.4 & 10.2 & 21 & 0.24 \\
\hline Storage time (month) & & $8.63(3.701)$ & $9.44(3.212)$ & $8.92(3.545)$ & $32.23 * * *$ \\
\hline \multirow{3}{*}{ Storage system } & Filling in sack/ $(\%)$ & 79.4 & 79.7 & 79.5 & \\
\hline & In granary $(\%)$ & 20.6 & 20.3 & 20.5 & \\
\hline & Expecting high price (\%) & 44.2 & 8.6 & 31.5 & \\
\hline Reason for store & Expecting high price \& takes time for dehulling & 5.8 & 10.3 & 7.4 & \\
\hline
\end{tabular}

$\mathrm{N}=$ Sample size $* * *$ value shows statistically significant at less than $1 \%$ significant level and figures in parenthesis indicate standard deviation Source: Survey result, 2017

Table 4 revealed that from the total, about $93.7 \%$ of sampled respondents were stored the groundnut product 
because expecting high price and lack of market demand. From the total sampled respondents of Woreta Zuria producers storing groundnut $96.9 \%$ longer time than that of Woji Arbamba almost $91 \%$ of the producers. However, storing means doesn't mean nothing sold soon after harvest rather they did not sale all amount produced once. And about from the sample producers $21 \%$ confirmed that they started to sale immediately the amount of groundnut after harvest in order to solve their current financial problem and like saved other crops, paid credit, relatively other crops it is costly etc. According to table 4 chi-square results presented that there was a statistically significant difference between storing of groundnut in the study areas at less than $1 \%$ level of significance.

An average storing time from the total sampled respondents were 8.92 months. This means producers were stored their groundnut until an average 8.92 months for expecting high price. As the t- test value revealed that from the Table 4 there was statistically significant difference between storing groundnut in the study areas at less than $1 \%$ significance level. Concerning about the storage system of groundnut from the total, almost $80 \%$ of the household heads were stored their groundnut by filling in sacks and put above the underneath of bed or stone and the rest $20 \%$ of the respondents stored their groundnut by granary. Regarding the reason for storing groundnut, about $61 \%$ of the total respondents were expecting high price and lack of market demand that means during that time there was low market price. And almost $32 \%$ of the respondents were storing groundnut for expecting high price and $7 \%$ of the respondents were due to expecting high price as well as removing the pod from the seed takes time (dehulling). As the chi-square test result from Table 4 revealed that there is statistically significant difference in the reasons of storing groundnut at less than $1 \%$ level of significance.

\subsection{Socio-Economic Characteristics of Sample Traders}

The result in Table 5 shows that the socio-economic characteristics of traders in terms of age, family size, sex, marital status, religion and educational level. As the survey result indicates that the average sampled traders' age was 33 years old and its standard deviation was 8.36. Gondar market traders were the youngest one as compared to Woji market traders (42.5 years). Based on the Table $5 \mathrm{t}$-value result revealed that there was statistically significant difference between the ages of groundnut traders at less than $1 \%$ level of significance. Family size differs from one market trader to the other market trader. As the result Table 5 presented that on average family size of sampled traders was 5 and its standard deviation was 1.6. There was also statistically significant difference among the family size of traders at less than $1 \%$ significance level.

The more experience of groundnut traders have, expecting the better access to market information to predict the future price, demand and supply than those who were less groundnut trading experience. From the sampled traders an average trading experience had 5 years of groundnut trading and its standard deviation was 1.84. And there is statistically significant difference between groundnut trading experiences of traders at less than $1 \%$ level of significance. Rural assemblers had more working experience regarding groundnut (7years) than the rest followed by Woreta and Debre-Tabour traders had more experience and exposure about groundnut trading of 5 years each respectively.

Concerning about sex, $77 \%$ of the sampled traders were males and the rest $23 \%$ were female groundnut traders. However, as Table 5 chi-square test result revealed that there was statistically significant difference on sex distribution of groundnut traders at less than $10 \%$ level of significance. This means, there existed the sex distribution of groundnut traders in the study areas. About $35 \%$ of the respondent traders were Orthodox Christian religion followers while the majorities $59 \%$ were Muslims and the remaining was no religion followers. From the sampled traders $18 \%$ were single while $79 \%$ was married and the rest $3 \%$ of the respondents were divorced in regard of marital status of traders among the markets. Hence, just like producers, the majority of the groundnut traders were also Muslim religion followers. Regarding the level of education of groundnut traders about $21 \%$ of the respondents did not attend formal schooling and $15 \%$ were attended primary school ( 1 to 4 grades). In addition, about $27 \%$ of the respondents were attended grade 5 to 8 and followed by $12 \%, 14 \%$ and $11 \%$ of the respondent who attended 9 to 12 grades, diploma and degree respectively. A study by [34] noted that education helps traders to acquire and process information which enable them to evaluate their decisions, plan and conduct their businesses with confidence which improves their business performance. Therefore, it is believed that the more educated the traders, the better to access market information about price, demand and supply and be able to make better business decision to make profitable their organization and improving the living standards.

Table 5. Demographic characteristics of traders versus its market centers (in average and percentage).

\begin{tabular}{|c|c|c|c|c|c|c|c|c|c|}
\hline Variables & Village & Woji & Alember & Woreta & Bahirdar & Debre-Tabour & Gondar & Total & t/ $\chi^{2}-$ value \\
\hline Age (years) & $39.5(0.71)$ & $42.5(3.54)$ & $\begin{array}{l}35.33 \\
(8.74)\end{array}$ & $\begin{array}{l}29 \\
(8.74)\end{array}$ & $35.4(8.82)$ & $32(4.36)$ & $28.25(6.34)$ & $33.03(8.36)$ & $23.044 * * *$ \\
\hline Family size & 5 & 6 & 5 & $5(1.35)$ & $5(2.54)$ & $5(1.16)$ & $4(1.16)$ & $5(1.6)$ & $17.37^{* * *}$ \\
\hline Experience (years) & $7(1.41)$ & $4(1.41)$ & $\begin{array}{l}5 \\
3\end{array}$ & $5(1.6)$ & $4(2.04)$ & $5(1.16)$ & $4(1.82)$ & $5(1.84)$ & $14.724 * * *$ \\
\hline Sex: Male (\%) Female (\%) & 100 & 100 & 100 & $\begin{array}{l}50 \\
50\end{array}$ & 100 & $\begin{array}{l}67 \\
33\end{array}$ & $\begin{array}{l}50 \\
50\end{array}$ & $\begin{array}{l}77 \\
23\end{array}$ & $10.843 *$ \\
\hline Religion Orthodox Chr. (\%) & & & & 50 & 30 & 67 & 50 & 35 & 17.774 \\
\hline
\end{tabular}




\begin{tabular}{|c|c|c|c|c|c|c|c|c|c|}
\hline Variables & Village & Woji & Alember & Woreta & Bahirdar & Debre-Tabour & Gondar & Total & t/ $\chi^{2}-$ value \\
\hline $\begin{array}{l}\text { Muslim (\%) No religion } \\
(\%)\end{array}$ & $\begin{array}{l}50 \\
50\end{array}$ & 100 & $\begin{array}{l}67 \\
33\end{array}$ & 50 & 70 & 33 & 50 & $\begin{array}{l}59 \\
6\end{array}$ & \\
\hline $\begin{array}{l}\text { Marital status Single (\%) } \\
\text { Married (\%) Divorced (\%) }\end{array}$ & 100 & 100 & 100 & $\begin{array}{l}30 \\
60 \\
10\end{array}$ & $\begin{array}{l}20 \\
80\end{array}$ & 100 & $\begin{array}{l}25 \\
75\end{array}$ & $\begin{array}{l}18 \\
79 \\
3\end{array}$ & 6.202 \\
\hline Edu. Level illiterate (\%) & & & & 10 & & & & 21 & \\
\hline Grade 1 to $4(\%)$ & 50 & & & 10 & 20 & & 25 & 15 & \\
\hline $\begin{array}{l}\text { Grade } 5 \text { to } 8(\%) \\
\text { Grade } 9 \text { to } 12(\%)\end{array}$ & & 50 & & $\begin{array}{l}30 \\
20\end{array}$ & $\begin{array}{l}50 \\
10\end{array}$ & & 25 & $\begin{array}{l}27 \\
12\end{array}$ & 38.411 \\
\hline Diploma (\%) & & & 67 & 10 & & 33 & 50 & 14 & \\
\hline Degree (\%) & & & & 10 & 10 & 67 & & 11 & \\
\hline
\end{tabular}

*** and * values show statistically significant at less than $1 \%$ and $10 \%$ significance level respectively and figures in parenthesis indicate standard deviation Source: Survey result, 2017

Traders' manpower: According to Table 6 indicated that other than the traders himself or herself, the groundnut business men employee assistants to help them. The average number of family of the sampled traders was three. The result in Table 6 clearly indicated that majority of the groundnut traders were employed daily based labors which mostly happened from urban wholesalers and processors i.e. one quintal of groundnut was sorted by an average thirty Birr and other daily labors had worked as sewing and filling sacks, shelf the quintal in the store. Average daily labor of the traders was one individual. However, in addition to daily labor, traders had permanent employees which had happened from processors. Average permanent employees of traders were two individual and the number of family members and total employees almost similar which were three individuals. This implies that groundnut trade is employee based business since the business by itself is labour intensive.

Table 6. Manpower of groundnut traders (in average) in 2015/16.

\begin{tabular}{|c|c|c|c|c|c|c|c|c|}
\hline & Village & Woji & Alember & Woreta & Bahirdar & Debre Tabour & Gondar & Total \\
\hline No of family member & 2 & $4(2.83)$ & $2(0.58)$ & $2(0.79)$ & $2(0.82)$ & $3(2.31)$ & $3(1.41)$ & $3(1.19)$ \\
\hline No of permanent employees & 2 & & $1(0.58)$ & $2(0.92)$ & $2(1.25)$ & $1(0.58)$ & $3(3.50)$ & $2(1.54)$ \\
\hline No of temporary employees & $\begin{array}{l}2 \\
(1.41)\end{array}$ & 1 & $1(1.16)$ & $1(0.70)$ & $2(2.23)$ & $1(0.58)$ & $2(0.75)$ & $1(1.43)$ \\
\hline Total employee & 4 & 1 & 2 & 3 & 4 & 2 & 5 & 3 \\
\hline
\end{tabular}

No which stands for number

Figures in parenthesis indicated that standard deviation

Source: Survey result, 2017

Market structure- conduct and performance of groundnut.

\subsubsection{Market Structure of Groundnut}

The market structure of groundnut was analyzed in terms of the degree of market concentration, barriers to entry (licensing procedure, lack of capital, knowhow and policy barriers), the degree of transparency [25]. In this subsection first the groundnut marketing participants and their role and linkage is discussed and followed by the discussions on the marketing channels and market concentration ratio.

\subsubsection{Groundnut Marketing Participants, Their Roles and Linkages}

In this study, different groundnut market participants were identified in the point of production to the point of consumption system of the various groundnut market participants in the study areas includes i.e. producers, rural assemblers, urban collectors, urban wholesalers, processors (oil processors, groundnut butter processors), Balitinas, urban retailers and street vendors. In the following paragraphs, the role of each actor and the interaction between and among the actors is presented.

Producers: Groundnut producers are the actors in the first stage of the market chain and they are the marketing agents who participate both in production as well as marketing of groundnut. Specifically, they harvest and transport groundnut to the nearest markets (village market) or woji or Woreta market themselves either by carrying themselves or using donkeys, over an average distance of 1 hour. They had different marketing options to sell their product, selling directly to rural assemblers or they sell to processors. Rural assemblers assembled large amount of groundnut from many producers in the study areas. Alternatively, producers also sold their product directly to the regional urban wholesalers even if the quantity sold was minimal as compared to rural assemblers.

Village markets are markets which are closest to the producers' resident, having less facility such as road. However, producers sell large quantity of groundnut in this market because of its distance. The majority of marketed agricultural products are transacted at regional market. This means that more amount of groundnut which was collected from the different sources and transacted at regional market since more buyers and seller were concentrated over this market. Hence, the proportion of the groundnut transacted via this actor was 100 percent. The role of producers were producing groundnut product and sold to the market and they are considered as the first stage supplier of the marketing channel. 
Rural assemblers: Rural assemblers who were marketing actors collect groundnut directly from producers in the village market for the purpose of reselling the purchased product to the urban wholesalers in the woreda market, regional market and to processors of zonal market. Their role was purchasing from producers and resale to the next marketing actors. They utilized their financial resources and marketing experience to purchase in bulk from the surrounding areas of producers. They did not incur transportation cost to purchase groundnut because producers can bring their produce till their working areas. However, for reselling the product to the processors such as in Gondar and Bahirdar market, they incurred transport cost. Finally, they supply the product to the next actors or customers (buyer). The proportion of the groundnut transacted via these actors was 66.7 percent.

Urban collectors: These are the marketing actors who were playing a role by purchasing groundnut directly from farmers and supplied to the urban wholesalers. They purchased in small quantity which accounts about 0.83 percent from the total amount of groundnut transacted due to lack of working capital as well as transportation facilities. Their linkage is considered as supplier of the next marketing actors or customers. Proportion of the groundnut transacted through these actors was 0.83 percent.

Urban wholesalers: Urban wholesalers are the major market actors in the marketing system that mostly purchase groundnut in larger volume from the marketing actors in the marketing channels and resell the products to processors, Balitinas and vendors than the final consumers. There primary role were purchasing groundnut from their preceding marketing actors and resale to the next groundnut marketing actors. Urban wholesalers buy groundnut product directly from rural assemblers, urban collectors as well as producers in minimal amount. Urban wholesalers incurred cost for sorting of the products in order to increase the quality of the product. The estimated amount of purchased groundnut from the total volume transacted was 81.75 percent.

Processors: These marketing actors who were purchasing groundnut directly from rural assemblers and or farmers for the purpose of processing the product into groundnut butter and groundnut oil and also these actors purchased groundnut product directly from regional as well as woreda urban wholesalers. The rural assemblers also sold the groundnut product to the Gondar market customers (groundnut butter processor) in addition the product, the rural assemblers while distributing the product to the Gondar market, they have been also brought their scaling for the purpose of measuring their product whereas the Bahirdar groundnut oil processor bought the product from urban wholesalers. They also processed the product and resale to the retailers and or consumers. Their linkages were the suppliers of the next actors. Proportion of the groundnut transacted passing through this actor was 97.72 percent.

Balitinas: These marketing actors purchasing groundnut directly from producers and urban wholesalers for the purpose of reselling to the urban retailers then final users.
These actors differ from processors; they processed groundnut in the roasted form with by adding spices, salt to increase the sweetness of the product which attracts more customers' as well increasing sales volume. The amount purchased was relatively less than that of processors which accounts the estimated total percentage share of $1.96 \%$.

Urban retailers: These marketing actors who were relatively concentrated in the regional as well as in the woreda towns. Retailers are traders in the marketing channel that sell the processed and or roasted form of groundnut products to the ultimate consumers (end users). Urban retailers who were groundnut traders purchased the product from their suppliers which were processors and Balitinas as well as in minimal amount from producers and their primary role were purchased the groundnut product from the former marketing actors and resale to the final destination (consumers) or end users. They were considered as the suppliers of the final destination of the market channel actors that were end users or consumers. The estimated amount of groundnut product purchased through these marketing actors from the total volume transacted was 99.69 percent.

Street vendors: These were also important marketing actors' and they purchase the product from urban wholesalers in the regional market as well as in the woreda town market for the purpose of processing in roasted form and resale to their buyers. Street vendors sold their product to the consumers by revolving around the town. Those who were deployed in this business were youngster and not married. Street vendors were marketing actors who purchased the quantity of groundnut in smaller quantity than the rest of groundnut traders. However, their benefit received birr per quintal were the leading one without considering opportunity cost. They did have their own measure what it is called highland cover. The proportion of the groundnut transacted via street vendors was $0.05 \%$ (2.2 quintals).

\subsubsection{Marketing Channels of Groundnut}

According to Mendoza (1995), marketing channel is the sequence of intermediaries through which whole groundnut passes from the point of producers to the point of end users. The analysis of marketing channel is expected to provide a systematic knowledge of the flow of goods and services from the point of production to the point of final destination. For this study, the major marketing channels were identified. Even though the actual marketing channel is diverse and complex, the main marketing channels of the 7 groundnut markets in terms of the quantity flow of groundnut product in 2015/16 was identified as follows:

I Producers $\rightarrow$ Processors $\rightarrow$ Consumers

II Producers $\rightarrow$ Urban retailers $\rightarrow$ Consumers

III Producers $\rightarrow$ Urban wholesalers $\rightarrow$ Street vendors $\rightarrow$ Consumers

IV Producers $\rightarrow$ Balitinas $\rightarrow$ Urban retailers $\rightarrow$ Consumers

V Producers $\rightarrow$ Urban wholesalers $\rightarrow$ Balitinas $\rightarrow$ Urban retailers $\rightarrow$ Consumers

VI Producers $\rightarrow$ Urban wholesalers $\rightarrow$ Processors $\rightarrow$ Urban 
retailers $\rightarrow$ Consumers

VII Producers $\rightarrow$ Rural assemblers $\rightarrow$ Processors $\rightarrow$ Urban retailers $\rightarrow$ Consumers

VIII Producers $\rightarrow$ Rural assemblers $\rightarrow$ Urban wholesalers $\rightarrow$ Processors $\rightarrow$ Urban retailers $\rightarrow$ Consumers

IX Producers $\rightarrow$ Urban collectors $\rightarrow$ Urban wholesalers $\rightarrow$ Processors $\rightarrow$ Urban retailers $\rightarrow$ Consumers

The groundnut market channels (Figure 2) were constructed based on the data collected from 7 markets. The result revealed that 9 major groundnut marketing channels were identified. Channel I is the shortest channel whereas channel VIII and IX were the longest channels. According to Figure 2 indicated that the smallest amount of groundnut receivers channel III was found producers - urban wholesalers - street vendors and consumers with an estimated volume of groundnut transacted was 2180.04, 2.2 and 2.2 quintals respectively whereas the largest groundnut product receivers were found in the marketing channel of VIII of producers-rural assemblers -urban wholesalersprocessors-urban retailers- consumers with an estimated volume of groundnut transacted was 4958, 2557.83, 4773.33, 7256.46 and 7256.46 quintals respectively.

Comparison was made based on the percentage share of groundnut that passed through each marketing channels. As figure 2 revealed that processors who were groundnut butter processors and groundnut oil processors were purchased groundnut product from the rural assemblers with the estimated proportion of 48.41 percent from the total amount of suppliers' groundnut purchased. Moreover, these processors also purchased from urban wholesalers with an estimated proportion of their total suppliers were 81.21 percent.

The operational meaning of Balitinas from this particular study was those groundnut product marketing actors who processed the groundnut product in roasted form and packed with by plastic and resale it by counting or befire rather than resale into by kilogram or canned form as processors. These marketing actors also differ from those street vendors of groundnut product traders were by their ways of selling, their customers, packaging materials as well as measurements. On the other hand, street vendors who were groundnut marketing actors, measure their product by what it called highland cover whereas Balitinas measure their product by counting it or befire. In addition, Balitinas' were purchased the volume of groundnut product more than that of marketing actors of street vendors.

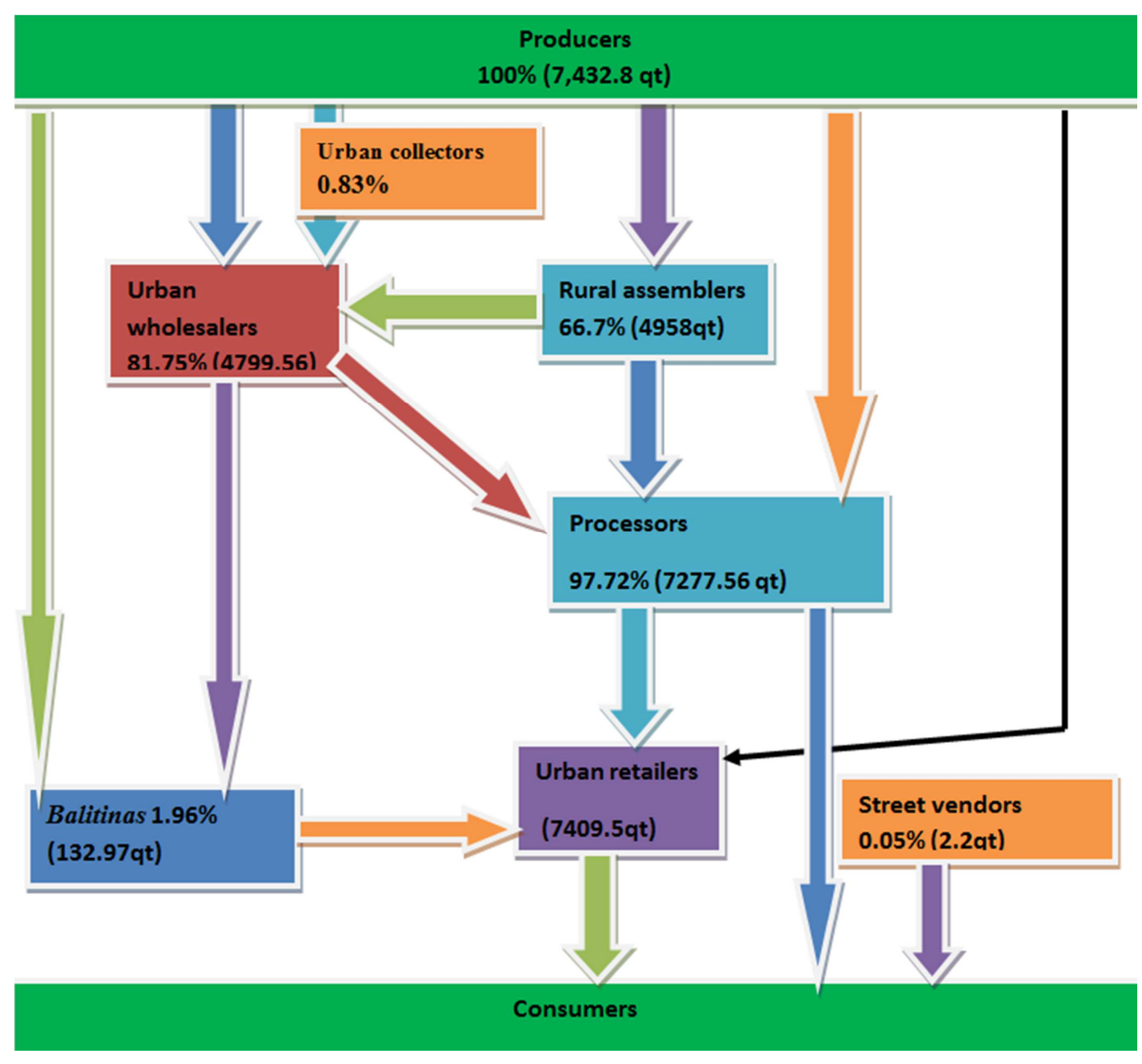

Sources: Survey result, 2017.

Figure 2. Groundnut marketing channels of 7 markets of 2015/16 percentage and quintals.

According to Figure 2 indicated that the proportion and the quantity of groundnut product marketed flows from the producer to consumers. Figure2 revealed that the market participants, their relationships and the choices available in different market participants in the buying or selling of groundnut as well as the estimated proportion and groundnut 
quantity marketed passing through the alternative channels were indicated. During the main season (autumn) the total production of groundnut was 12,525 quintals in Fogera woreda in 2015/16 production season [8]. From the total production and sampled respondents, the proportion of the marketing actors was $59.34 \%$ of groundnut product was transacted. The main types of groundnut traded were kernels, oil and groundnut butter. Therefore, from the total production and sample respondents, the volume of groundnut transacted was 7432.8 quintals.

According to Figure 2 presented that urban wholesalers and rural assemblers who were the primary actors in the groundnut marketing channels regarding more amount of producer's groundnut product purchased. The urban wholesalers' and rural assemblers' proportion of producers' groundnut in the identified marketing channels from the total quantity transacted were 29.33 percent (2180.04 quintal) and 66.7 percent (4958 quintal) respectively. And followed Balitinas, processors, urban collectors and urban retailers by proportion of $1.47,1.4,0.83$ and 0.27 percent with an estimated volume of groundnut transacted was 108.94,
104.06, 61.69 and 20.07 quintals respectively.

\subsubsection{Degree of Market Concentration}

The concentration ratio is expressed in terms of $\mathrm{CR}_{\mathrm{x}}$ which stands for the percentage of the market sector controlled by the biggest $\mathrm{X}$ firms. Four firms $\left(\mathrm{CR}_{4}\right)$ concentration ratio is the most typical method for judging the market structure [21]. According to the scholar, a $\mathrm{CR}_{4}$ of over $50 \%$ is generally considered as strong oligopoly; $\mathrm{CR}_{4}$ between $33 \%$ and $50 \%$ is considered as a weak oligopoly and a $\mathrm{CR}_{4}$ of less than $33 \%$ is unconcentrated market. In general, the higher the level of market concentration, the less perfectly competitive the market is.

In this study, the analysis of the degree of market concentration was carried out in Bahirdar market, where urban wholesalers and processors as well as retailers of the groundnut marketing actors were significantly involved. Concentration ratio was estimated by taking the annual volume of groundnut purchased in 2015/16 by sample traders. The survey result shows that in Bahirdar market groundnut trading was dominated by few sellers (Table 7).

Table 7. Concentration ratio of Bahirdar market 2015/16.

\begin{tabular}{|c|c|c|c|c|c|c|c|}
\hline $\begin{array}{l}\text { No of traders } \\
\text { (A) }\end{array}$ & $\begin{array}{l}\text { Cum freq. of } \\
\text { traders (B) }\end{array}$ & $\begin{array}{l}\text { \% of traders } \\
\left(\mathrm{D}=\frac{A}{34}\right)\end{array}$ & $\begin{array}{l}\text { Cum\% of } \\
\text { traders (E) }\end{array}$ & $\begin{array}{l}\text { Qty purchased } \\
\text { in qt }(\mathrm{F})\end{array}$ & $\begin{array}{l}\text { Total Qty purchased } \\
\text { in qt } G=A * F)\end{array}$ & $\begin{array}{l}\text { \% share of } \\
\text { purchase } S i=\frac{G}{7432.8}\end{array}$ & $\begin{array}{l}\% \text { Cum purchase } \\
\mathrm{C}=\sum_{\mathrm{I}=1}^{\mathrm{m}} \mathrm{Si}\end{array}$ \\
\hline 1 & 1 & 2.94 & 2.94 & 2400 & 2400 & 32.29 & 32.29 \\
\hline 1 & 2 & 2.94 & 5.88 & 1440 & 1440 & 19.37 & 51.66 \\
\hline 1 & 3 & 2.94 & 8.82 & 1000 & 1000 & 13.45 & 65.11 \\
\hline 1 & 4 & 2.94 & 11.76 & 855 & 855 & 11.5 & 76.61 \\
\hline 3 & 7 & 8.82 & 20.58 & 240 & 720 & 9.69 & 86.3 \\
\hline 1 & 8 & 2.94 & 23.53 & 322 & 322 & 4.33 & 90.63 \\
\hline 1 & 9 & 2.94 & 26.47 & 230 & 230 & 3.09 & 93.72 \\
\hline 1 & 10 & 2.94 & 29.41 & 120 & 120 & 1.61 & 95.33 \\
\hline 1 & 11 & 2.94 & 32.34 & 96 & 96 & 1.29 & 96.62 \\
\hline 1 & 12 & 2.94 & 35.28 & 45 & 45 & 0.61 & 97.23 \\
\hline 1 & 13 & 2.94 & 38.22 & 38.4 & 38.4 & 0.52 & 97.75 \\
\hline 2 & 15 & 5.88 & 44.10 & 24 & 48 & 0.65 & 98.4 \\
\hline 2 & 17 & 5.88 & 49.98 & 22.5 & 45 & 0.61 & 99.01 \\
\hline 1 & 18 & 2.94 & 52.92 & 20 & 20 & 0.27 & 99.28 \\
\hline 1 & 19 & 2.94 & 55.86 & 10.4 & 10.4 & 0.14 & 99.42 \\
\hline 1 & 20 & 2.94 & 58.80 & 8 & 8 & 0.11 & 99.53 \\
\hline 3 & 23 & 2.94 & 67.62 & 5.2 & 15.6 & 0.21 & 99.74 \\
\hline 1 & 24 & 2.94 & 70.56 & 3.08 & 3.08 & 0.04 & 99.78 \\
\hline 2 & 26 & 2.94 & 76.44 & 2.6 & 5.2 & 0.07 & 99.85 \\
\hline 1 & 27 & 2.94 & 79.38 & 2 & 2 & 0.03 & 99.88 \\
\hline 1 & 28 & 2.94 & 82.32 & 1.8 & 1.8 & 0.02 & 99.9 \\
\hline 1 & 29 & 2.94 & 85.26 & 1.68 & 1.68 & 0.03 & 99.93 \\
\hline 1 & 30 & 2.94 & 88.20 & 1.44 & 1.44 & 0.02 & 99.95 \\
\hline 1 & 31 & 2.94 & 91.14 & 1.32 & 1.32 & 0.02 & 99.97 \\
\hline 1 & 32 & 2.94 & 94.08 & 1.04 & 1.04 & 0.01 & 99.98 \\
\hline 1 & 33 & 2.94 & 97.02 & 0.96 & 0.96 & 0.01 & 99.99 \\
\hline 1 & 34 & 2.94 & 100 & 0.88 & 0.88 & 0.01 & 100 \\
\hline Total & 34 & & & & 7432.8 & 100 & \\
\hline
\end{tabular}

Source: Own computation, 2017

According to Table 7 presented that the four largest groundnut traders were handled 76.61 percent of the total volume of groundnut purchased in Bahirdar market. Based on the rule of thumb of market structure suggested by [21], the groundnut market in Bahirdar market shown strong oligopolistic market structure that indicates the existence of market imperfection. This means that the top four largest traders were controlling $76.61 \%$ of the groundnut market. The concentration ratio result indicated that there existed strong oligopoly market structure. This was due to, as compared to others, the four largest groundnut traders had better capital for purchasing volume of groundnut and entered into further processing the product than the rest of the groundnut traders. 


\subsubsection{Degree of Market Transparency}

Marketing information can help to predict, strategize, plan and act expediently, rationally and efficiently for running effectively the business, thus reducing business risk, transaction costs, and enabling market participants to explore and capitalize business opportunities [24]. Even though information plays significant role in improving the performance of marketing system, there was lack of organized system to provide reliable market information to all market participants in the study areas just like as other agricultural commodity of sesame, coffee etc.

Table 8. Traders sources of groundnut market information.

\begin{tabular}{llll}
\hline Sources & Frequency & Percentage & $\begin{array}{l}\text { Cumulative } \\
\text { percentage }\end{array}$ \\
\hline Other groundnut traders & 5 & 14.7 & 14.7 \\
Telephone & 25 & 73.5 & 88.2 \\
Personal observation & 4 & 11.8 & 100 \\
\hline
\end{tabular}

Source: Own computation, 2017

The result in Table8 shows that the sample traders used different sources to access market information. Among the total respondents $73.5 \%, 11.8 \%$ and $14.7 \%$ of the traders had obtained market information through telephone, other groundnut traders and personal observation respectively concerning about price, demand and supply in other markets. Hence, the main groundnut price information sources of sample traders were through telephone; although this was informal source of market information transfer mechanism might not be reliable because of frequent network interruption. Even though, Media i.e. television and radio play the greatest role in the provision of market information with a short period of time over wider area coverage, its effect in accessing groundnut market information to users was very limited.

Since sources and means of obtaining market information by traders varied significantly, the timelines and quality of information obtained depends on the traders' access to market information channels and their individual assumption on the level of supply, demand and price information collected from different sources in different times. About $88 \%$ of the sample traders stated their willingness to pay for information cost, if there are well organized, transparent and accessible information centers. As the market information sources in the study area were informal and not timely, it can be concluded that the market information was not transparent.

\subsubsection{Barriers to Entry and Exit of Groundnut Marketing}

Licensing procedure: The result from key informant interviews with traders show that trade licensing with respect to wholesaler registration requires an initial capital of 10,000 Birr in Bahirdar and the other registered with a capital of 40,000 Birr. To have trade license the trader should fulfill minimum requirements i.e. capital, kebele identification card, print (ashara) from customs and revenue office etc. From the rural assemblers one of the traders was registered with an initial working capital of Birr 50,000. As of the sample traders about $73 \%$ of the respondents have trade license with other product lines, almost $6 \%$ of the sample respondents did not have trade license and the rest $21 \%$ have trade license. From the sample trade, about almost $97 \%$ reported that getting trading license, the procedure was complicated and only $3 \%$ of the respondents suggested that if they fulfilled the minimum requirements, it was easy to have trading license. Hence, the traders reported that licensing procedure was considered as a discouraging factor for entry into the groundnut business.

Capital: The research finds out that about $97.1 \%$ of the sample traders lack working capital and this was one of the major traders' problems to run groundnut trading. To enter into the market capital is needed because they have to purchase more groundnut and they have to pay cash on hand at the time of purchase. In addition to this, lack of collateral and interest rate also impediment for getting credit from financial institutions which leads to entry barrier to entry into the industry and viewed as a constraining factor for expanding their operations, achieving efficiency, and storing the commodity for long time. In these cases, capital requirement discouraged entry into the groundnut trading. Due to this problem wholesalers and processors had purchased groundnut on credit and paid after selling their product.

\subsubsection{Market Conduct of Groundnut}

Market conduct refers to the firm's behavior for example pricing and selling policies and tactics, overt or tacit inter firm cooperation, or rivalry, and product or market related research and development activities [27]. In this section the market conduct of groundnut was analyzed in terms of the producer's and trader's price setting and purchasing strategies.

Price setting strategy: According to Table 9 result $58 \%$ of sample producers reported that market price was determined by the buyers / traders and 39\% of the sample producers' respondents suggested that selling price was determined by negotiation between sellers (producers) and buyers (traders). And only the rest $3 \%$ of the sample producers reported that selling price was determined by the demand and supply or current market price. This result in line with a research conducted at Malawi using S-C-P model of groundnut by [19] suggested that there were no trader-based organizations or marketing groups in all the markets to affect the bargaining power of marketing actors. Hence, the survey result also indicates that the groundnut market setting of prices was determined on individual basis.

Table 9. Mode of price determination of producers in 2015/16.

\begin{tabular}{llll}
\hline Price determined by & Frequency & Percentage & $\begin{array}{l}\text { Cumulative } \\
\text { percentage }\end{array}$ \\
\hline Negotiation with buyers & 68 & 39 & 39 \\
Current market price & 5 & 3 & 42 \\
Traders/ buyers & 101 & 58 & 100 \\
\hline
\end{tabular}

Source: Own computation, 2017

The behavior was reflected in purchase of produce from producers in that they were the traders who determine the 
price of the groundnut in the majority of the cases. The result confirmed that about $93 \%$ of the producers faced problems of lower price even if took to back and resold in another day same market as well as another day another market. About $27 \%$ of the sample household respondents reported that when the product was unsold, took back home and sold another market in another day with the existing price. And another ways of when the amount of product was unsold, about $10 \%$ of the sample producers reported that they took the product back home and waiting the next market day and sold in the same market. Hence, the majority price of producers that is $58 \%$ determined by traders indicates that 76.61 percent of the groundnut market dominated by a few numbers of traders in the study areas.

Concerning about the terms of payment the result in Table 10 shows that $88.8 \%$ of the sample producers sold their product on cash whereas about $11.2 \%$ reported that the terms of payment was made on credit with price advantages for producers in the future market. Moreover, it was indicated that there were no binding rules in this regard rather the agreement was made orally. Most of the sample producers suggested that price was the major influential factor that affects the producers' decision with respect to whom to sell and in which market to sell their produce of groundnut. This is also in line with the result of the concentration ratio that indicated the existence or absence of competitive pricing system which created deviation of competitive market conditions.

Table 10. Producers terms of payment in 2015/16.

\begin{tabular}{llll}
\hline Terms of payment & Frequency & Percentage & $\begin{array}{l}\text { Cumulative } \\
\text { percentage }\end{array}$ \\
\hline Cash & 150 & 88.8 & 88.8 \\
Credit & 19 & 11.2 & 100 \\
\hline
\end{tabular}

Source: Own computation, 2017

With respect to the payment mechanism, $96.6 \%$ of the sample respondents reported that payment was carried out in cash as soon as when sold their product. According to Table 11 only $3.4 \%$ of the survey result revealed that traders sold their product on credit and the buyer paid the amount of the product purchased on credit after it was sold.

This mostly due to lack of working capital at Bahirdar market (wholesaler) and while sellers sold on credit, they did not have binding agreement unless business loyalty. The result of the study shows that from the total sample traders' 71 percent of the respondents indicated that the purchasing of groundnut was carried out on 10 to $12 \mathrm{pm}$ (morning from 4 to 6 o'clock). During this time buyers and seller were reached in the transacted place and the market becomes hot.

Table 11. Traders' terms of payment in groundnut market in the study area of $2015 / 16$.

\begin{tabular}{llll}
\hline Terms of payment & Frequency & Percentage & Cumulative percentage \\
\hline Cash & 28 & 96.6 & 96.6 \\
Credit & 1 & 3.4 & 100 \\
\hline
\end{tabular}

Source: Own computation, 2017

\subsubsection{Analysis of Market Performance of Groundnut}

In this subsection, the market performance of groundnut was analyzed with respect to the marketing margins and the margin along each market channel is compared. The analysis was done based on the marketing costs and purchasing prices of the major market participants along with the chains. The analysis of marketing channels was intended to provide a systematic knowledge of the flow of goods and services from its origin of production to final destination (end users). Marketing margin can be a useful descriptive statistics if used to show how the consumers' expenditure is divided among market participants at different level of the marketing channels. Marketing margin is the difference in a price between what the producer receives for a certain product and the amount the consumer pays for an equivalent amount of that product.

Marketing margin is the percentage of the final average selling price taken by each stage of the marketing channels. The margin covers costs involving in transferring the product from one stage to the next and provided a reasonable return for those actors in the marketing channels. It can be expressed as a cost of providing a marketing mix of services. Hence, groundnut marketing margin was analyzed based on the estimated average sales price of the different marketing actors (rural assemblers, urban collectors, urban wholesalers, processors, Balitinas, urban retailers and street vendors) in the marketing channels.

The result in Table 12 clearly depicted that the total gross marketing margins (TGMM) among the different actors in different marketing channels added to groundnut price while passing to reach the final destination. The highest TGMM was registered in channel IX, VIII and VII which accounts the estimated percentage share of 64.81 percent and 64.05 percent each of the consumer's price respectively and followed by channel III which accounts for $60 \%$ of the consumer's price. From the total groundnut traders i.e. street vendors earn the highest gross marketing margin which had an estimated percentage share of $51 \%$ of the consumer price and followed by processors and urban retailers earn the second and third, highest gross marketing margin which had an estimated percentage share of $43.7 \%$ and $38.89 \%$ of the consumer's price respectively. This was due to the shortest marketing channels relatively than other marketing channels. Thus, the highest marketing margins taken by the different marketing actors along with the marketing channels were an evidence for the existence of market inefficiency i.e. low producers' price and high consumer price.

According to Table 12 urban wholesalers earn the lowest gross marketing margin which had an estimated percentage share of $7.04 \%$ and found in channel VIII of the consumer's price. This channel is also called one of the longest marketing channels of the marketing actors. This lowest gross marketing margin occurred due to the existence of high transaction costs associated with the marketing process i.e. storage loss, tax, transport and urban wholesalers did not go further processing the purchased groundnut product as compared to processors. 
Table 12. Marketing margin for groundnut traders in different marketing channels (Birr/qt).

\begin{tabular}{|c|c|c|c|c|c|c|c|c|c|}
\hline \multirow{2}{*}{$\begin{array}{l}\text { Marketing } \\
\text { margins }\end{array}$} & \multicolumn{9}{|c|}{ Marketing channels } \\
\hline & I & II & I & IV & $\mathbf{V}$ & VI & VII & VIII & IX \\
\hline TGMM & 43.70 & 38.89 & 60 & 59.77 & 59.78 & 59.77 & 64.05 & 64.05 & 64.81 \\
\hline $\mathrm{GMM}_{\mathrm{RA}}$ & & & & & & & 13.33 & 13.33 & \\
\hline $\mathrm{GMM}_{\mathrm{COL}}$ & & & & & & & & & 9.56 \\
\hline $\mathrm{GMM}_{\mathrm{WHL}}$ & & & 9 & & 13.08 & 13.08 & & 7.04 & 10.06 \\
\hline GMMPROS & 43.70 & & & & & 30.42 & 24.01 & 27.41 & 18.48 \\
\hline $\mathrm{GMM}_{\mathrm{BAL}}$ & & & & 22.63 & 22.13 & & & & \\
\hline $\mathrm{GMM}_{\mathrm{RTL}}$ & & 38.89 & & 37.14 & 24.57 & 16.27 & 26.71 & 16.27 & 26,71 \\
\hline $\mathrm{GMM}_{\mathrm{VEN}}$ & & & 51 & & & & & & \\
\hline $\mathrm{GMM}_{\mathrm{PRD}}$ & 56.3 & 61.11 & 40 & 40.23 & 40.22 & 40.23 & 35.95 & 35.95 & 35.19 \\
\hline $\mathrm{NMM}_{\mathrm{RA}}$ & & & & & & & 11.15 & 11.15 & \\
\hline $\mathrm{NMM}_{\mathrm{COL}}$ & & & & & & & & & 8.82 \\
\hline $\mathrm{NMM}_{\mathrm{WHL}}$ & & & 6.04 & & 10.1 & 10.1 & & 4.06 & \\
\hline $\begin{array}{l}\mathrm{NMM}_{\mathrm{PROS}} \\
\mathrm{NMM}_{\mathrm{PU}}\end{array}$ & 39.83 & & & & $10-8$ & 27.79 & 21.38 & 24.78 & \\
\hline $\mathrm{NMM}_{\mathrm{RTL}}$ & & 37.71 & & $\begin{array}{l}20.04 \\
36.43\end{array}$ & $\begin{array}{l}19.54 \\
23.86\end{array}$ & 15.56 & 26 & 15.56 & \\
\hline $\mathrm{NMM}_{\mathrm{VEN}}$ & & & 50.42 & & & & & & \\
\hline
\end{tabular}

Source: Own computation, 2017

The lowest TGMM was found in channel II; which accounts the estimated percentage share of $38.89 \%$ in the consumer's price and the highest TGMM found in the longest channel of IX which accounts the estimated percentage share of $64.81 \%$ of the consumer's price and the highest percentage share of producer's $\left(\mathrm{GMM}_{\mathrm{PRD}}\right)$ was found in channel II; which accounts $61.11 \%$ of the consumer's price. The highest the producer's share earns due to the fact that the smallest the price spread in the marketing channels, the less distributed the marketing benefit among the marketing actors along with the marketing channels. The lowest gross marketing margin of producer's earn in the longest channel of VII, VIII and IX which had an estimated percentage share of $35.95 \%$ each and $35.19 \%$ respectively of the consumer's price. This result with the agreement of [31] which analyzed the structure, conduct, and performance of the Ethiopian grain market that found low producer's share. The reason for the same producer's share was the producers sold their groundnut product by the same price to the traders/buyers. The producer's share $\left(\mathrm{GMM}_{\mathrm{PRD}}\right)$ was less than $50 \%$ of the consumer's price in all the marketing channels except in channel I and II.

As the result in Table 12 presented that among the different marketing actors in the marketing channel, street vendors got the highest net marketing margin $\left(\mathrm{NMM}_{\mathrm{VEN}}\right)$ which accounted for $50.42 \%$ the consumer's price; this was due to the fact that street vendors had incurred less cost as compared to other marketing actors in the marketing channels and followed by the processors which accounts the net gross marketing margin of $39.83 \%$ found in channel I of the consumer's price. This is because the price spread was less which means the shortest marketing channels and better product process takes place in these marketing actors in the marketing channels. However, the calculation of net marketing margin did not include opportunity costs rather accounting cost. The lowest net marketing margin earned by the urban wholesalers which accounted for about $4.06 \%$ in the longest marketing channels (VIII) of the consumer's price; this was the reason that urban wholesalers incurred the highest cost i.e. storage loss, transport and did not go further processing the product as compared to processors or Balitinas.

\section{Conclusions}

Production of groundnut in the study area is mainly for market. Groundnut is an important source of cash income for households. This study indicated that groundnut is one of the major cash crops in the study area and it is transacted by diverse marketing actors via nine major marketing channels. The market structure of groundnut is found to be characterized by strong oligopoly market structure as more than three fourth of the total volume of the groundnut is shared by the largest four firms in the market. Furthermore, barriers to entry or exit in the groundnut business such as shortage of capital, bureaucratic licensing procedures, limited market linkage, and non-transparent market structure are the constraints that make the market to be more imperfect.

The market conduct of groundnut is dominated the decision made by the traders in the majority of the cases. With respect to the price setting strategy, about $58 \%$ of producers reported that groundnut price was determined by buyers/traders and in this regard $93 \%$ of the respondents faced problems of lower price. The implication is that the pricing strategy is not competitive pricing system. Regarding the terms of payment about $88.8 \%$ of the sample producers sold their product with the payment effected at spot market. Whereas, $11.2 \%$ of the producers indicated that the payment was made on credit mostly by the agreement made orally with the buyers.

The result shows that the imperfect market structure and the market conduct that was skewed to the traders has been resulted by market performance in which the vendors had the highest marketing margin $(51 \%)$ followed by processors 
(43.7\%) and urban retailers (38.89\%) in channel III, I and II of the consumer's price respectively. In addition, vendors had the highest NMM which accounts $50.42 \%$ of the consumer price found in channel III because of low cost incurred without considering opportunity cost. However, urban wholesalers earn the lowest gross marketing margin and NMM with an estimated share of $7.04 \%$ and $4.06 \%$ respectively. The highest TGMM is found in channel IX which accounts the estimated share of $64.81 \%$ of the consumer's prices and the lowest estimated producer's share found in channel IX was $35.19 \%$ of the consumer's price. On the contrary, the lowest TGMM was found in channel II which accounts the estimated share of $38.89 \%$ of the consumer's price and the highest GMM of producer was $61.11 \%$ in channel II of the consumer's price.

\section{Recommendations}

Based on the results and discussions the following recommendations are forwarded:

(1) The strong oligopolistic market structure which is also characterized by the pricing setting strategy in favor of the traders, establishing cooperatives for smallholder groundnut producers is imperative for increasing the producers bargaining power so as to reduce the market inefficiencies due to the strong oligopolistic market structure. Hence, the cooperative are believed to encourage the producers to supply the product regularly as well as via at affordable price. This is also believed to make possible fair benefit of the market chain actors.

(2) Since sources and means of obtaining market information by traders varied significantly, the timelines and quality of information obtained depends on the traders' access to market information channels and their individual assumption on the level of supply, demand and price information collected from different sources in different times. About $88 \%$ of the sample traders stated their willingness to pay for information cost, if there are well organized, transparent and accessible information centers. As the market information sources in the study area were informal and not timely, it should be recommended that using Media i.e. television and radio play the greatest role in the provision of market information with a short period of time over wider area coverage.

(3) The result from this study shows that traders with license are already at a disadvantage and could not be competitive in buying and selling of the product especially wholesalers because the absence of measure on the unlicensed traders who do not have the obligation to pay taxes. Because they adversely affect the licensed traders by buying the product at higher price and sold it relatively at lower price as compared to licensed traders. Hence, making protection for licensed traders is crucial. In this regard, public authorities in collaboration with representatives of traders should devise a means of controlling those engaged in unfair market competitiveness.

\section{References}

[1] Abay Akalu 2007. Vegetable Market Chain Analysis in Amhara National Regional State: The Case of Fogera Woreda, South Gondar. MSc. Thesis, Department of Agricultural Economics, School of Graduate Studies, Haramaya University.77-78pp.

[2] Abrham Feyissa 2009, Grain marketing and Livelihoods in Ethiopia. A case of structure, conduct and performance of grain market in Lume Wereda of Oromia region.4pp

[3] Alemnew Abay 2010. Market Chain Analysis of Red Pepper: The Case of Bure Woreda, West Gojjam Zone, Amhara National Regional State, Ethiopia. MSc. Thesis, presented to the School of Agricultural Economics and Agribusiness Management, Haramaya University. 10pp.

[4] ADLI (Agricultural Development Lead Industrialization), 2001. Rural Development Policies and Strategies: Department of press and Audiovisual, Ministry of Information. Addis Ababa, Ethiopia.2pp.

[5] Astewel Takele 2010. Analysis of Rice Profitability and Marketing Chain: The Case of Fogera Woreda, South Gondar Zone, Amhara National Regional State, Ethiopia. MSc. Thesis, presented to the College of Agriculture, Department of Agricultural Economics, School of Graduate Studies, Haramaya University.76pp.

[6] Bain, J. S. (1968). Industrial Organization, $2^{\text {nd }}$ ed., John Wiley and Sons, New York.

[7] Berhane Sibhatu, Guesh Tekle and Melesse Harfe. 2016. Response of groundnut to different rates of phosphorus fertilizer at Tanqua- Abergelle District, Northern Ethiopia. Basic Research Journal. 5(1). 24-29.

[8] BOARD (Bureau of Agriculture and Rural Development). 2016. The Woreda Annual report, Woreta.

[9] Cramer, G. L. and Jensen, W. 1982. Agricultural Economics and Agribusiness, $2^{\text {nd }}$ Edition. McGraw Hill Book Company, USA. 222pp.

[10] CSA (Central Statistical Agency). 2009. Agricultural sample survey.2009. Addis Ababa, Ethiopia.

[11] Daniel Admasu, Wondafrash Mulugeta, and Sintayehu Admas.2007. Performance of groundnut varieties in the lowlands of North Shewa. In: Proceedings of the 2nd Annual Regional Conference on Completed Crops Research Activities18 - 21 September 2007, Bahir Dar, Ethiopia.

[12] Eleni Gebre-Medhin, 2003. Market institutions, transaction costs, and social capital in the Ethiopian grain market. International Food Policy Research Institute. USA.

[13] Geleta, T., Purshotum K. S., Wijnand S., Tana T. (2007). Integrated management of groundnut root rot using seed quality. International Journal of Pest Management.

[14] Gelgelo Kibi 2014. Design and Development of Groundnut Sheller. MSc. Thesis, Presented to the School of Natural Resources and Environmental Engineering, School of Graduate Studies, Haramaya University. 
[15] Habekiristos Beyene. 2016. Large and Medium Scale Commercial Farms Annual Survey, the Domino Effect of World Bank Intervention, Challenges and Innovative Approaches the Experience of Ethiopia. Director of Agriculture, Natural Resource and Environment Statistics Washington DC. pp.3.

[16] IPMS (Improved Productivity and Market Success).2016. Fogera Wereda pilot learning Site Diagnosis and program Design, Woreta.

[17] Jema Haji, 2008. An Economic Efficiency and Marketing Performance of Vegetables in Eastern and Central part of Ethiopia doctorial thesis, Nov., 2008, Sweden.

[18] Jenkins, K. and Phiri, D. 2009. Peace Corps Zambia. Life PreService Training Technical Manual.

[19] Joseph Dzanja and Bonnet Kamwana.2014. Structure, Conduct and Performance of Groundnuts Markets in Northern and Central Malawi: Case Studies of Mzimba and Kasungu Districts. Department of Agribusiness Management, Lilongwe University of Agriculture and Natural Resources, Lilongwe Malawi. 5(6). 132-137.

[20] Kindie Aysheshm 2007. Sesame Market Chain Analysis: The Case of Metema Woreda, North Gondar Zone, Amhara National Regional State. MSc. Thesis, Department of Agricultural Economics, School of Graduate Studies, Haramaya University.1-38pp.

[21] Kohl, R. L. and Uhl, J. N. 1985, Marketing of Agricultural Product, $5^{\text {th }}$ Edition, Collier Macmillan, USA. 624pp.

[22] Mendoza, G. 1995. A primer on marketing channels and margins. Lyme Rimer Publishers Inc, USA

[23] NBE (National Bank of Ethiopia).2013. National Bank of Ethiopia Annual Report 2012/13. Addis Ababa, Ethiopia.

[24] Odendo $M$ and De Groote.2007. Linking Producers to Markets: The case of Grain Marketing Information in Western Kenya. Kenya Agricultural Research Institute (KARI), Nairobi, Kenya.
[25] Pender J., Ruben R., Jabbar M. and Eleni, Gebre-Medhin.2004 Policies for improved land management and agricultural land management and agricultural market development in the Ethiopian highlands. In: Proceedings of summary of papers workshop, February 19-20, 2004, IFPRI, held at Ghion Hotel, Addis Ababa, Ethiopia. pp. 3-24.

[26] Rehima Mussema 2006. Analysis of Red Pepper Marketing: the case of Alaba and Silitie in SNNPRS, Ethiopia. MSc. Thesis Presented to School of Graduate Studies of Haramaya University. 43-103pp.

[27] Scarborough, V. and Kiddy, J. 1992. Economic Analysis of Agricultural Markets: A manual. Chatham, U. K. Natural Resource Institute.

[28] Shughart, William F. 1990. The Organization of Industry. Richard O. Irwin Inc, U.S.A.

[29] Thomas, C. R. and Maurice, S. C. (2011) Managerial Economics: Foundations of Business Analysis and Strategy, $10^{\text {th }}$ Edition.

[30] Wijnands, J. H. M., Biersteker J., Van Loo E. N. 2009. Oil seed business opportunity in Ethiopia. Oil seed research report. Addis Ababa, Ethiopia.

[31] Wolday Amha and Eleni G/medhin, 2003. An analysis of the Structure, Conduct, and Performance of the Ethiopian Grain Market, Addis Ababa.

[32] Wolday, Amha. 1994. Food Grain Marketing Development in Ethiopia after Reform 1990, a Case Study of Alaba Siraro. The PhD Dissertation, Presented to Verlag Koster University.

[33] Yamane, Taro. 1967. Statistics, an Introductory Analysis. $2^{\text {nd }}$ ed. New York-Harper and Row.

[34] Zhou, K. Z., Li, J. J., Zhou, N. and Su, C. 2008. Market orientation, job satisfaction, product quality and firm performance: Evidence from China. Strategic Management Journal, 29(9): 985-1000. 